\title{
Cyclic ADP-ribose and the pancreatic beta cell: where do we stand?
}

\author{
M. S. Islam, P.-O. Berggren \\ The Rolf Luft Center for Diabetes Research, Department of Molecular Medicine, Karolinska Institute, Stockholm, Sweden
}

A model for the beta-cell stimulus-secretion coupling, postulating a central role for cyclic adenosine $5^{\prime}$ diphosphate ribose (cADPR) in glucose stimulated increase in cytoplasmic, free $\mathrm{Ca}^{2+}$ concentration $\left(\left[\mathrm{Ca}^{2+}\right]_{\mathrm{i}}\right)$ has been proposed by Dr. Okamoto and colleagues. The origin of this model dates back to 1993 when the first report [1] and accompanying editorial in Science [2] depicted it as a significant advancement in our understanding of $\mathrm{Ca}^{2+}$-signalling in these cells. In this model, cADPR releases $\mathrm{Ca}^{2+}$ from endoplasmic reticulum (ER) by activating the ryanodine receptor (Ry) and $\mathrm{Ca}^{2+}$ released from ER plays an important role in stimulating insulin secretion. Furthermore Dr. Okamoto maintains that beta cells do not possess a mechanism for $\mathrm{Ca}^{2+}$ release by inositol $(1,4,5)$ trisphosphate $\left(\operatorname{Ins}(1,4,5) \mathrm{P}_{3}\right)$ [1]. Through a series of studies the authors have produced evidence for a messenger role of cADPR and importance of Ry in glucose-stimulated increase in $\left[\mathrm{Ca}^{2+}\right]_{i}[3]$. Okamoto et al's interest in the NAD metabolite cADPR appears to stem from their earlier works where they demonstrate a crucial role for the cellular level of NAD in mediating diverse processes such as beta cell damage and beta cell tumour formation [4].

\section{Background}

Lee et al. [5] identified the structure of an active metabolite, i.e. cADPR responsible for the $\mathrm{Ca}^{2+}$-releasing

Corresponding author: Dr. Md. S. Islam, Department of Molecular Medicine, Karolinska Institute, Karolinska Hospital, L1:02, S-17176 Stockholm, Sweden

Abbreviations. $\left[\mathrm{Ca}^{2+}\right]$, Ambient free $\mathrm{Ca}^{2+}$ concentration; $\left[\mathrm{Ca}^{2+}\right]_{\mathrm{i}}$, Intracellular free calcium concentration; cADPR, cyclic adenosine $5^{\prime}$ diphosphate ribose; $\operatorname{Ins}(1,4,5) \mathrm{P}_{3}$, inositol $(1,4,5)$ trisphosphate; Ry, ryanodine receptor; ER, endoplasmic reticulum; CICR, $\mathrm{Ca}^{2+}$-induced $\mathrm{Ca}^{2+}$ release. effect of $\beta$-NAD ${ }^{+}$in sea urchin eggs. It has since been demonstrated that cADPR also releases $\mathrm{Ca}^{2+}$ from intracellular non-mitochondrial stores in many mammalian cells [6]. These studies suggest that cADPR activates an intracellular $\mathrm{Ca}^{2+}$ channel having the pharmacological properties of Ry [7]. Early reactions to the discovery of cADPR was that this molecule is the endogenous ligand for Ry just as Ins $(1,4,5) \mathrm{P}_{3}$ is the natural ligand for its receptor [8]. The enzymatic mechanisms for synthesis and degradation of cADPR have been characterized and the enzymes are known to be present in many cells. Despite this remarkable progress, some uncomfortable controversies have emerged regarding the physiological role of cADPR and even its $\mathrm{Ca}^{2+}$-mobilizing effect. From this point of view, the case of the pancreatic beta cell is noteworthy because it was the first cell type where a physiological role for cADPR in mediating stimulus-secretion coupling was claimed [1]. In this commentary, we shall analyse the controversial aspects of cADPR in beta cells and attempt to identify possible reasons for such differences.

Does cADPR release $\mathrm{Ca}^{2+}$ from intracellular stores in insulin-secreting cells?

The claim that cADPR and not $\operatorname{Ins}(1,4,5) \mathrm{P}_{3}$ releases $\mathrm{Ca}^{2+}$ from intracellular stores in beta cells [1] was immediately questioned [9]. This controversy promoted other studies. To date, three groups have examined the role of cADPR in a range of insulin-secreting cells, e.g. RINm5F cells, ob/ob mouse beta cells [9], the glucose-responsive cell line INS-1 and rat islet cells [10-12]. The methods used in these studies for detecting $\mathrm{Ca}^{2+}$-release by cADPR include use of permeabilized cells and measurements of $\left[\mathrm{Ca}^{2+}\right]$ by $\mathrm{Ca}^{2+}$-selective electrodes, or fluo-3 [9, 10], measurements of $\mathrm{Ca}^{2+}$-activated $\mathrm{K}^{+}$current by patch-clamp 
technique [9] and use of the microinjection technique [12]. Despite use of a variety of insulin-secreting cells, an array of sensitive methods, and different experimental approaches, neither a $\mathrm{Ca}^{2+}$-releasing effect nor any other role of CADPR has been revealed in these studies.

Thus, to date, demonstration of $\mathrm{Ca}^{2+}$-release by cADPR in insulin-secreting cells is limited to the studies carried out by Okamoto et al. In their experiments $\mathrm{Ca}^{2+}$ release by cADPR is highly reproducible. The reasons for such differences between results reported by Okamoto et al. and those reported by others have remained unclear. It is however obvious that the conditions of experiments where cADPR is reported to release $\mathrm{Ca}^{2+}$ are markedly different from those of experiments where it does not. Thus, Takasawa et al. [1] obtain $\mathrm{Ca}^{2+}$ release by cADPR when they use islet microsomes and an incubation buffer of high salt concentration. It is possible that in beta cells $\mathrm{Ca}^{2+}$ release by cADPR is demonstrable only from islet microsomes and only under particular incubation conditions. Studies that question $\mathrm{Ca}^{2+}$-release by cADPR have not attempted to exactly duplicate the study of Takasawa et al. [1]. There seems, however, little incentive to do so. Such studies would require large numbers of islets which cannot be readily obtained. Moreover, the methods used in collection of large numbers of rat islets and preparation of microsomes from them, make it inevitable that significant contamination from alpha and delta cells, endothelial cells, fibroblasts, acinar cells and even lymph nodes, vessels and ducts may occur [13]. These latter cells may contain Ry in abundance (compared to low level of the receptor in beta cells) which may complicate interpretation of results obtained from islet microsome studies.

Other experimental conditions could also affect $\mathrm{Ca}^{2+}$ release by cADPR in different cells. Thus, $\mathrm{Ca}^{2+}$ release by cADPR characteristically requires calmodulin which may be diluted under conditions of experiments that do not obtain a release by the cyclic nucleotide [14]. Because of the uncertainty as to whether such critical conditions for CADPR action were perturbed in experiments with permeabilized cells and patch-clamp experiments, Webb et al. [12] directly examined the effect of cADPR under more physiological conditions using intact beta cells and the microinjection technique. It was still not possible to detect a rise in $\left[\mathrm{Ca}^{2+}\right]_{\mathrm{i}}$ by microinjected cADPR. Furthermore, microinjection of a cADPR-antagonist did not block a glucose-induced rise in $\left[\mathrm{Ca}^{2+}\right]_{i}[12]$. Essentially similar results have been reported by Willmott et al. [11] in rat beta cells.

Rutter et al. [10] reported a small increase in ambient $\left[\mathrm{Ca}^{2+}\right]$ after addition of cADPR and this they attributed entirely to contamination of cADPR with $\mathrm{Ca}^{2+}$. Investigators working with other cell types have also been concerned with the possibility of contamination of cADPR with $\mathrm{Ca}^{2+}$ and this prompted them to conduct a series of control experiments to rule this out [15].

\section{Ins $(1,4,5) P_{3}$ as $\mathrm{Ca}^{2+}{ }_{-}$mobilizing second messenger in beta cells}

According to the studies of Takasawa et al. [1], Ins $(1,4,5) \mathrm{P}_{3}$ is not a calcium-mobilizing second messenger in beta cells. This view is clearly at odds with the standard view. According to the authors, early studies demonstrated $\mathrm{Ca}^{2+}$ release by $\operatorname{Ins}(1,4,5) \mathrm{P}_{3}$ from microsomes or permeabilized cells because those studies used transformed cells. Some support for this view is available from immunocytochemical studies of beta cells [16] and experiments that directly compared the $\operatorname{Ins}(1,4,5) \mathrm{P}_{3}$-induced $\mathrm{Ca}^{2+}$ release in tumoural and native beta cells [10]. The latter experiments confirm that Ins $(1,4,5) \mathrm{P}_{3}$ releases much less $\mathrm{Ca}^{2+}$ from native beta cells as compared to the tumoural ones [10]. In spite of these, the notion that beta cells entirely lack mechanisms for $\mathrm{Ca}^{2+}$ release by $\operatorname{Ins}(1,4,5) \mathrm{P}_{3}$, is inconsistent with numerous studies demonstrating formation of Ins $(1,4,5) \mathrm{P}_{3}$ on stimulation of phosphoinositide-specific phospholipase C-linked receptors and release of $\mathrm{Ca}^{2+}$ from intracellular stores by the inositol trisphosphate in permeabilized cells [17-20].

\section{Ryanodine receptor in insulin-secreting cells}

The mechanism of $\mathrm{Ca}^{2+}$ release by cADPR in any cell involves an indirect effect of the cyclic nucleotide on Ry. However, convincing evidence to support the view that Rys play significant role in $\mathrm{Ca}^{2+}$-signalling in beta cells, is still lacking. In intact or permeabilized insulin-secreting cells, caffeine, an agonist of Ry, releases little or no $\mathrm{Ca}^{2+}$ from intracellular stores [9, $10,17]$. Activating concentrations of ryanodine or its $\beta$-alanyl analogue also do not yield a detectable increase in $\left[\mathrm{Ca}^{2+}\right]_{\mathrm{i}}$ in beta cells $[21,22]$. Gromada et al. [23] demonstrated evidence for involvement of Ry in glucagon-like peptide-I-induced increase in $\left[\mathrm{Ca}^{2+}\right]_{\mathrm{i}}$ in insulin-secreting cells, while others have presented conflicting evidence [24]. Nevertheless, there are bits and pieces of data suggesting the presence of a Rylike channel in insulin-secreting cells, albeit at a low level $[18,22,25]$. Islet from $o b / o b$ mice, insulin-secreting $\beta$-TC3 cells and RINm5F cells express mRNA for Ry [26, 27]. Moreover, this Ry appears to be type 2, a type that according to some reports, is sensitive to cADPR [27, 28]. It is possible that low and perhaps labile expression of Ry in beta cells together with subtle differences in the experimental conditions used by different investigators accounts for different conclusions drawn regarding the existence of Rys and their importance in beta cells. 


\section{cADPR-binding protein/receptor}

A recent claim that FKBP12.6 may be the intracellular receptor for cADPR is a novel one [29]. However, we need to see whether this finding can be reproduced. It may be noted that earlier studies that identified cADPR-binding proteins by photoaffinity labelling did not detect any protein with a molecular weight of FKBP12.6 [30].

\section{cADPR level in glucose-stimulated beta cells}

Does glucose stimulation increase cADPR level in beta cells? According to Takasawa et al. [1], it does. The authors prepared extracts from beta cells treated in high glucose conditions and demonstrated that these extracts released more $\mathrm{Ca}^{2+}$ from islet microsomes compared with that released by extracts prepared from low glucose-treated cells. Although this was the only way to address the question at a time when no other suitable method was available for cADPR measurement, we do not believe that any meaningful conclusion can be drawn from such experiments. This is because extracts prepared from high glucose-treated cells, are likely to contain not only high levels of $\mathrm{Ca}^{2+}$ to start with but also other $\mathrm{Ca}^{2+}$-mobilizing agents such as $\operatorname{Ins}(1,4,5) \mathrm{P}_{3}$ and arachidonic acid. Recent studies that have measured cADPR in beta cells by radioimmunoassay have not been able to demonstrate a detectable rise in cADPR level on stimulation by glucose [31].

\section{Role of intracellular $\mathrm{Ca}^{2+}$ stores in glucose-stimulated insulin secretion}

$\mathrm{Ca}^{2+}$ entry through voltage-gated $\mathrm{Ca}^{2+}$ channels appears to be essential for increasing $\left[\mathrm{Ca}^{2+}\right]_{\mathrm{i}}$ after stimulation by glucose [19]. Against this background, the role of glucose in releasing $\mathrm{Ca}^{2+}$ from intracellular stores and thereby stimulating secretion appears quantitatively less important. Thus, although $\mathrm{Ca}^{2+}$ mobilizing signalling molecules such as $\operatorname{Ins}(1,4,5) \mathrm{P}_{3}$ and arachidonic acid are generated on stimulation by glucose [20,32], it has seldom been possible to demonstrate directly that glucose stimulation causes net release of $\mathrm{Ca}^{2+}$ from intracellular stores. Numerous studies have demonstrated that when $\left[\mathrm{Ca}^{2+}\right]_{\mathrm{i}}$ is raised solely by release of the ion from intracellular stores, there is only a small and transient stimulation of insulin secretion $[33,34]$. Furthermore, depletion of intracellular $\mathrm{Ca}^{2+}$ stores by thapsigargin appears to have little effect on glucose-stimulated $\mathrm{Ca}^{2+}$-oscillation or insulin secretion [35]. This does not rule out the possibility that $\mathrm{Ca}^{2+}$ entering through the voltage-gated $\mathrm{Ca}^{2+}$ channels is amplified by $\mathrm{Ca}^{2+}$-induced $\mathrm{Ca}^{2+}$ release (CICR) [18], a process that could be modulated by $\operatorname{Ins}(1,4,5) \mathrm{P}_{3}$ or cADPR. To what extent such amplification occurs and the quantitative importance of different $\mathrm{Ca}^{2+}$ release channels in mediating CICR remain to be carefully studied.

\section{cADPR-metabolizing enzymes in beta cells}

Beta cells express two bifunctional enzymes CD38 and bone marrow stromal antigen 1 (BST-1) involved in synthesis and degradation of cADPR [36]. CD38 catalyses at its extracellular domain the synthesis of cADPR from $\beta-\mathrm{NAD}^{+}$as well as hydrolysis of cADPR to ADP ribose. Transgenic mice, overexpressing CD38 in beta cells manifest increased insulin secretion in response to glucose [3]. This has been attributed to increased formation of cADPR by CD38 and consequent increased release of $\mathrm{Ca}^{2+}$ from intracellular stores. CD38, however, appears to be involved in many physiological functions and other mechanisms by which it might affect secretion may need to be considered. For instance, CD38 can possibly act as an ADP-ribosylating enzyme and may induce insulin secretion by ADP-ribosylation of proteins including G-proteins $[37,38]$. Whether in transgenic mice, CD38 overexpression may enhance insulin secretion by subtle effects on development and growth of beta cells also needs to be explored.

\section{Difficulties in demonstrating $C a^{2+}$-release by $c A D P R$ in other cells}

The controversy regarding the $\mathrm{Ca}^{2+}$-mobilizing effect of cADPR and its significance is not unique to beta cells. In the heart, it has been demonstrated that cADPR releases $\mathrm{Ca}^{2+}$ from isolated sarcoplasmic reticulum vesicles and activates Ry incorporated in the planar lipid bilayer [28]. However, the results could not be reproduced by others [39, 40]. Liver cells do not seem to express mRNA of any of the known Rys, but cADPR has still been reported to release $\mathrm{Ca}^{2+}$ from nuclear envelops of these cells [41]. On the other hand Lilly and Gollan [42] demonstrate that cADPR does not release $\mathrm{Ca}^{2+}$ from hepatic microsomes. The list could be longer.

\section{Conclusions}

Dr. Okamoto's hypothesis that cADPR is a signalling molecule coupling glucose metabolism to increase in $\left[\mathrm{Ca}^{2+}\right]_{\mathrm{i}}$ in beta cells is interesting. The doubts derive from a failure by other investigators to reproduce their main finding, i.e. $\mathrm{Ca}^{2+}$-release by cADPR in beta cells. Even if it is accepted that cADPR might release $\mathrm{Ca}^{2+}$ from intracellular stores in beta cells, the stand taken by Dr. Okamoto seems exaggerated 
when he regards this mechanism as one of primary importance. However, the intriguing observations made in studies with transgenic mice, may point to some modulatory role of cADPR in insulin secretion. Whether cADPR and CD38 may affect secretion in beta cells by mechanisms unrelated to the postulated $\mathrm{Ca}^{2+}$-mobilizing effect needs to be explored. At present $\mathrm{Ca}^{2+}$ release by cADPR and its role as a messenger molecule, remain controversial even in cells where Rys are expressed in plentiful numbers. Such controversies should provide incentives for future studies directed at molecular characterization of intracellular $\mathrm{Ca}^{2+}$ channels and elucidation of their quantitative importance in mediating CICR in beta cells.

Acknowledgements. Financial support was obtained from the Swedish Medical Research Council (03X-09890, 19X-00034), Juvenile Diabetes Foundation International (JDFI), Nordic Insulin Foundation Committee, Swedish Diabetes Association, The Swedish Society of Medicine and Funds of the Karolinska Institute. M.S. I. has a position at the Swedish Medical Research Council.

\section{References}

1. Takasawa S, Nata K, Yonekura H, Okamoto H (1993) Cyclic ADP-ribose in insulin secretion from pancreatic $\beta$-cells. Science 259: 370-373

2. Galione A (1993) Cyclic ADP-ribose: a new way to control calcium. Science 259: 325-326

3. Kato I, Takasawa S, Akabane A et al. (1995) Regulatory role of CD38 (ADP-ribosyl cyclase/cyclic ADP-ribose hydrolase) in insulin secretion by glucose in pancreatic $\beta$ cells: enhanced insulin secretion in CD38-expressing transgenic mice. J Biol Chem 270: 30045-30050

4. Okamoto H, Yamamoto H (1983) DNA strand breaks and poly(ADP-ribose) synthetase activation in pancreatic islets - a new aspect to development of insulin-dependent diabetes and pancreatic $\beta$-cell tumors. Princess Takamatsu Symp 13: 297-308

5. Lee HC, Walseth TF, Bratt GT, Hayes RN, Clapper DL (1989) Structural determination of a cyclic metabolite of $\mathrm{NAD}^{+}$with intracellular $\mathrm{Ca}^{2+}$-mobilizing activity. $\mathrm{J}$ Biol Chem 264: 1608-1615

6. Sitsapesan R, McGarry SJ, Williams AJ (1995) Cyclic ADP-ribose, the ryanodine receptor and $\mathrm{Ca}^{2+}$ release. Trend Pharmacol Sci 16: 386-391

7. Galione A, Lee HC, Busa WB (1991) $\mathrm{Ca}^{2+}$-induced $\mathrm{Ca}^{2+}$ release in sea urchin egg homogenates: modulation by cyclic ADP-ribose. Science 253: 1143-1146

8. Berridge MJ (1993) Cell signalling. A tale of two messengers. Nature 365: 388-389

9. Islam MS, Larsson O, Berggren P-O (1993) Cyclic ADP-ribose in $\beta$ cells. Science 262: 584-585

10. Rutter GA, Theler J-M, Li G, Wollheim CB (1994) $\mathrm{Ca}^{2+}$ stores in insulin-secreting cells: lack of effect of cADP ribose. Cell Calcium 16: 71-80

11. Willmott NJ, Galione A, Smith PA (1995) A cADP-ribose antagonist does not inhibit secretagogue-, caffeine- and nitric oxide-induced $\mathrm{Ca}^{2+}$ responses in rat pancreatic $\beta$-cell. Cell Calcium 18: 411-419

12. Webb DL, Islam MS, Efanov AM et al. (1996) Insulin exocytosis and glucose-mediated increase in cytoplasmic free
$\mathrm{Ca}^{2+}$ concentration in the pancreatic $\beta$-cell are independent of cyclic ADP-ribose. J Biol Chem 271: 19074-19079

13. van Suylichem PTR, Wolters GH, van Schilfgaarde R (1993) The efficacy of density gradients for islet purification: a comparison of seven density gradients. Transplant Int 3: 156-161

14. Lee HC, Aarhus R, Graeff R, Gurnack ME, Walseth TF (1994) Cyclic ADP ribose activation of the ryanodine receptor is mediated by calmodulin. Nature 370: $307-$ 309

15. Guse AH, Dasilva CP, Emmrich F, Ashamu GA, Potter BVL, Mayr GW (1995) Characterization of cyclic adenosine diphosphate-ribose-induced $\mathrm{Ca}^{2+}$ release in T lymphocyte cell lines. J Immunol 155: 3353-3359

16. Ravazzola M, Halban PA, Orci L (1996) Inositol 1,4,5-trisphosphate receptor subtype 3 in pancreatic islet cell secretory granules revisited. Proc Natl Acad Sci USA 93: 27452758

17. Islam MS, Larsson O, Nilsson T, Berggren P-O (1995) Effects of caffeine on cytoplasmic free $\mathrm{Ca}^{2+}$ concentration in pancreatic $\beta$-cells are mediated by interaction with ATPsensitive $\mathrm{K}^{+}$channels and L-type voltage-gated $\mathrm{Ca}^{2+}$ channels but not the ryanodine receptor. Biochem J 306: 679686

18. Islam MS, Rorsman P, Berggren P-O (1992) $\mathrm{Ca}^{2+}$-induced $\mathrm{Ca}^{2+}$ release in insulin-secreting cells. FEBS Lett 296: 287291

19. Theler J-M, Mollard P, Guérineau N et al. (1992) Video imaging of cytosolic $\mathrm{Ca}^{2+}$ in pancreatic $\beta$-cells stimulated by glucose, carbachol, and ATP. J Biol Chem 267: 1811018117

20. Morgan NG, Rumford GM, Montague W (1985) Studies on the role of inositol trisphosphate in the regulation of insulin secretion from isolated rat islets of Langerhans. Biochem $\mathbf{J}$ 228: $713-718$

21. Islam MS, Kindmark H, Larsson O, Berggren P-O (1997) Thiol oxidation by 2,2'-dithiodipyridine causes a reversible increase in cytoplasmic free $\mathrm{Ca}^{2+}$ concentration in pancreatic $\beta$-cells: role for inositol 1,4,5-trisphosphate-sensitive $\mathrm{Ca}^{2+}$ stores. Biochem J 321: 347-354

22. Li G, Wollheim CB, Pralong WF (1996) Oscillations of cytosolic free calcium in bombesin-stimulated HIT-T15 cells. Cell Calcium 19: 535-546

23. Gromada J, Dissing S, Bokvist K, et al. (1995) Glucagonlike peptide I increases cytoplasmic calcium in insulin-secreting $\beta$-TC3-cells by enhancement of intracellular calcium mobilization. Diabetes 44: 767-774

24. Holz GG IV, Leech CA, Habener JF (1995) Activation of a cAMP-regulated $\mathrm{Ca}^{2+}$-signaling pathway in pancreatic $\beta$ cells by the insulinotropic hormone glucagon-like peptide1. J Biol Chem 270: 17749-17757

25. Hellman B, Gylfe E, Grapengiesser E, Lund PE, Berts A (1992) Cytoplasmic $\mathrm{Ca}^{2+}$ oscillations in pancreatic $\beta$-cell. Biochim Biophys Acta 1113: 295-305

26. Bennett DL, Cheek TR, Berridge MJ et al. (1996) Expression and function of ryanodine receptors in nonexcitable cells. J Biol Chem 271: 6356-6362

27. Islam MS, Leibiger I, Leibiger B et al. (1996) Expression of ryanodine receptor genes in islets and effects of ryanodine receptor-agonists on cytoplasmic free $\mathrm{Ca}^{2+}$ concentration in $\beta$-cells. Diabetologia 39: A50 (abstract)

28. Mészáros LG, Bak J, Chu A (1993) Cyclic ADP-ribose as an endogenous regulator of the non-skeletal type ryanodine receptor $\mathrm{Ca}^{2+}$ channel. Nature 364: 76-79

29. Noguchi N, Takasawa S, Nata K et al (1997) Cyclic ADP-ribose binds to FK506-binding protein 12.6 to release $\mathrm{Ca}^{2+}$ from islet microsomes. J Biol Chem 272: 3133-3136 
30. Walseth TF, Aarhus R, Kerr JA, Lee HC (1993) Identification of cyclic ADP-ribose-binding proteins by photoaffinity labeling. J Biol Chem 268: 26686-26691

31. Malaisse WJ, Kanda Y, Inageda K, Scruel O, Sener A, Katada T (1997) Cyclic ADP-ribose measurements in rat pancreatic islets. Biochem Biophys Res Commun 231: 546-548

32. Wolf BA, Turk J, Sherman WR, McDaniel ML (1986) Intracellular $\mathrm{Ca}^{2+}$ mobilization by arachidonic acid. Comparison with myo-inositol 1,4,5-trisphosphate in isolated pancreatic islets. J Biol Chem 261: 3501-3511

33. Hermans MP, Henquin JC (1989) Relative importance of extracellular and intracellular $\mathrm{Ca}^{2+}$ for acetylcholine stimulation of insulin release in mouse islets. Diabetes 38: 198-204

34. Nilsson T, Arkhammar P, Hallberg A, Hellman B, Berggren P-O (1987) Characterization of the inositol 1,4,5-trisphosphate-induced $\mathrm{Ca}^{2+}$ release in pancreatic $\beta$-cells. Biochem J 248: 329-336

35. Liu YJ, Grapengiesser E, Gylfe E, Hellman B (1995) Glucose induces oscillations of cytoplasmic $\mathrm{Ca}^{2+}, \mathrm{Sr}^{2+}$ and $\mathrm{Ba}^{2+}$ in pancreatic $\beta$-cells without participation of the thapsigargin-sensitive store. Cell Calcium 18: 165-173

36. Kajimoto Y, Miyagawa J, Ishihara K et al. (1996) Pancreatic islet cells express BST-1, a CD38-like surface molecule having ADP-ribosyl cyclase activity. Biochem Biophys Res Commun 219: 941-946

37. Grimaldi JC, Balasubramanian S, Kabra NH et al. (1995) CD38-mediated ribosylation of proteins. J Immunol 155: 811-817

38. Quist EE, Coyle DL, Vasan R, Satumtira N, Jacobson EL, Jacobson MK (1994) Modification of cardiac membrane adenylate cyclase activity and $\mathrm{G}_{\mathrm{s} \alpha}$ by NAD and endogenous ADP-ribosyltransferase. J Mol Cell Cardiol 26: 251260

39. Fruen BR, Mickelson JR, Shomer NH et al. (1994) Cyclic ADP-ribose does not affect cardiac or skeletal muscle ryanodine receptors. FEBS Lett 352: 123-126

40. Guo XQ, Laflamme MA, Becker PL (1996) Cyclic ADP-ribose does not regulate sarcoplasmic reticulum $\mathrm{Ca}^{2+}$ release in intact cardiac myocytes. Circ Res 79: 147-151

41. Gerasimenko OV, Gerasimenko JV, Tepikin AV, Petersen OH (1995) ATP-dependent accumulation and inositol trisphosphate- or cyclic ADP-ribose-mediated release of $\mathrm{Ca}^{2+}$ from the nuclear envelope. Cell 80: 439-844

42. Lilly LB, Gollan JL (1995) Ryanodine-induced calcium release from hepatic microsomes and permeabilized hepatocytes. Am J Physiol 268: G1017-G1024 